\title{
Dual Trigger Crosslinked Micelles Based Polyamidoamine for Effective Paclitaxel Delivery
}

\section{Kien Voon Kong ${ }^{1 *}$, Douglas Goh ${ }^{1}$ and Malini Olivo ${ }^{1,2}$}

${ }^{1}$ Bio-Optical Imaging Group, Singapore Bioimaging Consortium, Agency for Science Technology and Research (A*STAR), 11 Biopolis Way, 138667, Singapore ${ }^{2}$ School of Physics, National University of Ireland Galway, Galway, Ireland

\begin{abstract}
Targeted delivery of drugs in therapeutic applications is gaining traction in treating various diseases. However, its practicality is challenged by uncontrolled drug release. We present here a novel dual-trigger polyamidoaminebased crosslinked micelle vector that releases therapeutic drugs in response to triggers. The degradation of micelles can be controlled by redox and MMP-2 enzymatic activities. Such a system can achieve greater specificity for drug release than most recently reported micelle systems. Cytotoxicity tests of the micelles showed that they posed significantly lower toxicity towards normal cells as normal cells have relatively lower concentration of MMP-2 enzyme to disintegrate the micelles. The paclitaxel-conjugated micelles were effective in inducing apoptosis and cell cycle arrest in MDA-MB-231 cancer cells. The results demonstrated that the degradation of polyamidoamines could be fine-tuned by an enzyme-active peptide, thus increasing the anti-tumour efficacy and pave the way for development of highly controllable targeted drug delivery platforms.
\end{abstract}

Keywords: Polymeric micelles; Drug delivery; Biodegradable; Matrix metalloproteases; Epidermoid carcinoma

\section{Introduction}

Polymeric micelles are one of the most promising drug delivery systems. Their successes and limitations have prompted the continual search for new polymeric delivery systems [1-7]. One of the current challenges in drug delivery applications is to liberate therapeutic agents at specified times and locations. Releasing therapeutic agents can be achieved through degradation of micelles triggered by biological stimuli. Most widely used biological stimuli are $\mathrm{pH}$ changes, redox reactions, and presence of enzyme [8-10]. The advantage of degradation of polymeric micelles is that degraded polymeric micelles are efficiently excreted from the body [11].

Redox-triggered degradation of polymeric micelles is one of the most recognized biodegradation processes in therapeutic delivery. Micelles are formed from polymers bearing disulfide bonds which are generally stable in the circulation system and prone to rapid cleavage under a reductive environment through thiol-disulfide exchange reaction $[12,13]$. The higher concentration of glutathione (GSH) in tumor cells allows the attractive use of redox-responsive degradable polymers for drug delivery [14]. Several redox-responsive poly(amidoamine) compounds which contain many disulfide bonds, secondary and tertiary amines in the backbone through Michaeladdition polymerization were reported for gene or drug delivery [15]. Other than fast degradation, they offer the distinct advantages of easy tunability of their topology by varying the polymerization temperature or monomer ratios, the availability of multiple sites for the attachment of various ligands as property modifiers such as targeting-specific ligands, and poly(ethylene)glycol (PEG) stealth layers.GSH is present in both cancer and normal cells. Although, normal cells have lower concentration of GSH, this low concentration can also cause redoxdegradation of micelles which makes the delivery system non-specific, causing deleterious side-effects of therapeutic delivery systems. An ideal delivery system should be one that is able to eliminate this nonspecific degradation process.

Other than the problem of non-specificity, stability of micelles is a common limitation in most polymeric micelles for drug delivery applications in which they spontaneously dissociate upon intravenous administration as dilution in blood circulation causes premature release of therapeutic agents [16,17]. The crosslinked micelles, first coined by Wooley in 1996, are actively developed to overcome the issue of instability. Redox-responsive crosslinker has been used to stabilize micelles as demonstrated by Armes [18-20]. To date, there have been a number of reports suggesting that crosslinked micelles may hold promise in drug delivery applications [21]. Unfortunately, most of these reported crosslinked micelles consist of a non-biodegradable polymer backbone, which may take a long time to be excreted. Retention in the body can cause lysosomal storage disease syndrome upon repeated drug application [22]. Lipoic acid modified biodegradable micelles have recently been reported and shown a reversibly formed stable micelle. Lipoic acid is a naturally occurring pro-vitamin rendering itself ideal for biomedical applications [23-25]. In light of this, lipoic acid will be used to enhance stability of polymeric micelles and is, thus, incorporated into the copolymer backbone in the current study. Our main objective was to fine-tune the process of degradation of crosslinked redoxresponsive micelles under conditions designed to mimic its behaviour in the cytoplasm. We hypothesize that enzyme-active peptide could be an effective crosslinker in tuning the rate of degradation of lipoic acid crosslinked redox-responsive micelles, thereby increasing antitumor efficacy. These micelles were characterized for stability, drug release, in vitro cytotoxicity, intracellular uptake and ability to induce cell cycle arrest and apoptosis in MDA-MB-231 cancer cells.

Several important aspects of tumor enzymes have been exploited for targeted release. Matrix metalloproteases (MMPs), a family of

*Corresponding author: KV Kong, Bio-Optical Imaging Group, Singapore Bioimaging Consortium, Agency for Science Technology and Research (A*STAR), 11 Biopolis Way, 138667, Singapore, Tel: (65) 6478 8752; Fax: (65) 6478 9957; E-mail: KONG_kien_voon@sbic.a-star.edu.sg

Received June 19, 2014; Accepted July 21, 2014; Published July 26, 2014

Citation: Kong KV, Goh D, Olivo M (2014) Dual Trigger Crosslinked Micelles Based Polyamidoamine for Effective Paclitaxel Delivery. J Nanomed Nanotechnol 5: 212. doi: 10.4172/2157-7439.1000212

Copyright: $\odot 2014$ Kong KV, et al. This is an open-access article distributed under the terms of the Creative Commons Attribution License, which permits unrestricted use, distribution, and reproduction in any medium, provided the original author and source are credited. 
proteolytic enzymes, have been causally implicated in tumor invasion and angiogenesis [26-35]. Much research has been devoted to MMPs, especially MMP-2. MMP-2 is over-expressed in many cancers, including breast cancers, and is a sign of tumor angiogenesis and metastasis; MMP2 expression level is statistically higher in cancerous breast cells than in normal ones. To date, targeted release based on MMPs activity has been pursued by conjugating MMP-sensitive peptide to polymeric carrier, and therapeutic agents were released from polymeric carrier once the MMPs peptide substrate was cleaved [36-40]. However, the use of MMPsensitive peptide for variation of degradation rate polymeric micelles to improve selective degradation for improvement of delivery specificity has not been widely explored. In this study, we use paclitaxel (PTX) as a model drug for our delivery system. The advantage of polymerdrug conjugates over other formulations such as Taxol" is that no toxic solubilizing agent, Cremophor EL, is present, and Enhanced Permeability and Retention (EPR) effect is enhanced [41-45]. The conjugation of PTX onto poly(AMPD-BAC)-g-PEG is similar to that of PEG such that it forms a carbamate linkage that is hydrolytically stable [46-48]. PNU166945, a potential PTX polymeric conjugate, has entered clinical trials. However, it suffers from poor pharmacokinetics in phase I due to instability of ester linkage conjugating PTX [49]. It is thus expected that favourable pharmacokinetic properties of carbamate linked PTX allow it to be stable in the circulatory system. The significance of this work lies in the high degree of control exerted over the micelles properties and the potential of this platform technology for other applications.

\section{Materials and Methods}

\section{Materials}

4-aminomethyl piperidine (AMPD, Alfa Aesar), N,N`-bis(acryloyl) cystamine (BAC, polysciences), paclitaxel (PTX, Yunnan Hande BioTech Co. Ltd, China), dithiothreitol (DTT, Sigm-Aldrich), 4-nitrophenyl chloroformate (Fluka), lipoic acid (Sigma), monomethyl poly(ethylene glycol) (Mw: 2000, Sigma-Aldrich), acrylic acid N-hydroxy succinimide ester (Sigma) and catalytic domains of MMP-2 (Biomol) were from commercial sources and used without further purification. MMP-2 sensitive peptide was designed based on the known MMP-2 substrate sequence, and was synthesized by Shanghai Hanhong Chemical Co., Ltd. with $98 \%$ purity [50]. All other starting materials were purchased from Aldrich. Methyl poly(ethylene)glycol-4-nitrophenyl carbonate [51], and 2'-[4-Nitrophenyl-carbonate]paclitaxel were prepared according to the literature method $[52,53]$. MCF-10A cell lines were purchased from the American Type Culture Collection (ATCC). MDA-MB-231 and MCF-10A cells were grown in culture flasks with Dulbecco's Modified Engle Medium (DMEM, Invitrogen) containing $10 \%$ fetal bovine serum (FBS, Invitrogen), 1\% L-glutamate (GIBCO Laboratories) and 1\% penicillin-streptomycin (GIBCO Laboratories) at $37^{\circ} \mathrm{C}$ in a $5 \% \mathrm{CO}_{2}$ incubator. Phosphate buffered saline (PBS) was purchased from ${ }^{1 s t}$ BASE. The cyctotoxicity assay were performed with 3-(4,5-Dimethylthiazol-2-yl)-2,5-Diphenyltetrazolium Bromide (MTT, Duchefa Biochemie).

\section{General procedure}

${ }^{1} \mathrm{H}$ NMR spectra were recorded on a Bruker DRX-400 NMR spectrometer; chemical shifts reported were referenced against the residual proton signals of the solvents. Molecular weight was determined from gel permeation chromatography (GPC) implemented on a Waters 2690 apparatus with Water Ultrahydrogel 250 and 200 columns, a Waters 410 refractive index detector, and a miniDAWN light scattering detector (Wyatt Technology) using $0.2 \mathrm{M}$ acetic acid/ $0.2 \mathrm{M}$ sodium acetate as eluent at a flow rate of $0.75 \mathrm{~mL} / \mathrm{min}$. A Brookhaven
BI-9000AT Digital Autocorrelator was used for dynamic light scattering (DLS) measurements with $90^{\circ}$ scattering angle laser light of wavelength $632.8 \mathrm{~nm}$. Transmission electron microscopy (TEM) images were obtained on a Philips CM300 FEGTEM instrument at $300 \mathrm{kV}$. The samples were prepared by dipping holey copper meshes covered with carbon into an aqueous solution of samples followed by drying in air.

\section{Synthesis of linear polymer poly (AMPD-BAC)}

The polymer was synthesized by Michael-addition polymerization. BAC (6.14 g, $25 \mathrm{mmol})$ was dissolved in $40 \mathrm{~mL}$ dry methanol at room temperature. AMPD (2.88 g, $25 \mathrm{mmol})$ was added to the solution while stirring. The mixture was stirred at room temperature for 30 days. The resulted solution was dialyzed against methanol for five times to remove unreacted monomers.

Yield $=6.80 \mathrm{~g}(71 \%)$.

${ }^{1} \mathrm{H}$ NMR ( $\left.\mathrm{CH}_{3} \mathrm{OD}\right): \delta 1.24\left(\mathrm{~m}, 2 \mathrm{H}, \mathrm{CH}_{2}\right), 1.52$ (bs, $\left.1 \mathrm{H}, \mathrm{CH}\right), 1.75$ (d, $\left.2 \mathrm{H}, \mathrm{CH}_{2}\right), 2.03\left(\mathrm{t}, 4 \mathrm{H}, \mathrm{CH}_{2}\right), 2.38\left(\mathrm{t}, 4 \mathrm{H}, \mathrm{CH}_{2}\right), 2.49\left(\mathrm{~d}, 2 \mathrm{H}, \mathrm{CH}_{2}\right), 2.65(\mathrm{t}$, $\left.2 \mathrm{H}, \mathrm{CH}_{2}\right), 2.83\left(\mathrm{t}, 4 \mathrm{H}, \mathrm{CH}_{2}\right), 2.95\left(\mathrm{~d}, 2 \mathrm{H}, \mathrm{CH}_{2}\right), 3.49\left(\mathrm{t}, 4 \mathrm{H}, \mathrm{CH}_{2}\right)$.

\section{Synthesis of poly (AMPD-BAC)-g-PEG}

Poly (AMPD-BAC) $(6.0 \mathrm{~g}, 16.0 \mathrm{mmol})$ in $60 \mathrm{~mL}$ dry dimethylsulfone was added to PEG 4-nitrophenyl carbonate $(5.83 \mathrm{~g}, 2.6 \mathrm{mmol})$. The mixture was stirred at room temperature for five days. The resulted solution was dialyzed against methanol for 4 times to remove unreacted PEG. The solvent was removed under reduced pressure to afford poly(AMPD-BAC)-g-PEG as a water soluble solid.

Yield $=7.40 \mathrm{~g}(73 \%)$

${ }^{1} \mathrm{H}$ NMR ( $\left.\mathrm{CH}_{3} \mathrm{OD}\right): \delta 1.24\left(\mathrm{~m}, 2 \mathrm{H}, \mathrm{CH}_{2}\right), 1.52(\mathrm{bs}, 1 \mathrm{H}, \mathrm{CH}), 1.75$ (d, $\left.2 \mathrm{H}, \mathrm{CH}_{2}\right), 2.03\left(\mathrm{t}, 4 \mathrm{H}, \mathrm{CH}_{2}\right), 2.38\left(\mathrm{t}, 4 \mathrm{H}, \mathrm{CH}_{2}\right), 2.49\left(\mathrm{~d}, 2 \mathrm{H}, \mathrm{CH}_{2}\right), 2.65(\mathrm{t}$, $\left.2 \mathrm{H}, \mathrm{CH}_{2}\right), 2.83\left(\mathrm{t}, 4 \mathrm{H}, \mathrm{CH}_{2}\right), 2.95\left(\mathrm{~d}, 2 \mathrm{H}, \mathrm{CH}_{2}\right), 3.49\left(\mathrm{t}, 4 \mathrm{H}, \mathrm{CH}_{2}\right), 3.63$ (s, b, $\mathrm{OCH}_{2} \mathrm{CH}_{2}$ ), 4.14 (bs, $2 \mathrm{H}, \mathrm{CH}_{2}$ ).

\section{Synthesis 2'-[4-nitrophenyl-carbonate] paclitaxel}

Pyridine $(1 \mathrm{~mL})$ was added into a solution of paclitaxel $(2.0 \mathrm{~g}, 2.34$ $\mathrm{mmol})$ in $15 \mathrm{~mL}$ dry dichloromethane under argon atmosphere. At $-50^{\circ} \mathrm{C}$, 4-nitrophenyl chloroformate $(1.89 \mathrm{~g}, 9.36 \mathrm{mmol})$ dissolved in 10 $\mathrm{mL}$ dichloromethane was added. The reaction mixture was stirred for 4 $\mathrm{h}$. The product was precipitated from the reaction mixture using diethyl ether. The solid was collected and purified by re-precipitation from a diethyl ether solution.

Yield: $1.20 \mathrm{~g}(50.30 \%)$

${ }^{1} \mathrm{H}$ NMR (CDCl3): $\delta 1.13\left(\mathrm{~s}, 3 \mathrm{H}, \mathrm{CH}_{3}\right), 1.21\left(\mathrm{~s}, 3 \mathrm{H}, \mathrm{CH}_{3}\right), 1.69(\mathrm{~s}$, $\left.3 \mathrm{H}, \mathrm{CH}_{3}\right), 1.80$ (s, 3H, $\mathrm{CH}_{3}$ ), 2.22 (s, 3H, OAc), 2.38 (s, 3H, OAc), 3.78 (d, $1 \mathrm{H}, \mathrm{CH}), 4.19$ (d, 2H, $\left.\mathrm{CH}_{2}\right), 4.30(\mathrm{~d}, 2 \mathrm{H}, \mathrm{CH}), 4.40$ (dd, $\left.1 \mathrm{H}, \mathrm{CH}\right)$, $4.82(\mathrm{~d}, 1 \mathrm{H}, \mathrm{CH}), 4.94(\mathrm{~d}, 1 \mathrm{H}, \mathrm{CH}), 5.66(\mathrm{~d}, 1 \mathrm{H}, \mathrm{CH}), 5.78(\mathrm{dd}, 1 \mathrm{H}, \mathrm{CH})$, $6.20(\mathrm{t}, 1 \mathrm{H}, \mathrm{CH}), 6.25(\mathrm{~s}, 1 \mathrm{H}, \mathrm{CH}), 6.94(\mathrm{~d}, 1 \mathrm{H}, \mathrm{NH}), 7.26$ (s, aromatic), $7.40(\mathrm{~m}$, aromatic), 7.47 (d, nitrophenyl), 7.58 (m, aromatic), $7.79(\mathrm{~m}$, aromatic), 8.11 ( $\mathrm{m}$, aromatic), 8.76 (d, nitrophenyl).

\section{Synthesis of poly (AMPD-BAC)-g-PEG-PTX}

2'-[4-Nitrophenyl-carbonate] paclitaxel $(4.37 \mathrm{~g}, 2.0 \mathrm{mmol})$ and triethylamine $(1 \mathrm{~mL})$ was added to poly(AMPD-BAC)-g-PEG(6.0 $\mathrm{g}, 1.10 \mathrm{mmol}$ ) in $60 \mathrm{~mL}$ dimethylsulfone. The mixture was stirred at room temperature for $24 \mathrm{~h}$. The resulted solution was dialyzed against methanol for five times. The solvent was removed under reduced pressure to afford poly (AMPD-BAC)-g-PEG-PTX as a water soluble transparent liquid. 
Yield $=5.80 \mathrm{~g}(77 \%)$

${ }^{1} \mathrm{H}$ NMR (CDCl3): $\delta 1.15$ (s, 3H, $\left.\mathrm{CH}_{3}\right), 1.33\left(\mathrm{~m}, 2 \mathrm{H}, \mathrm{CH}_{2}\right), 1.67$ (s, $\left.3 \mathrm{H}, \mathrm{CH}_{3}\right), 1.83\left(\mathrm{~d}, 2 \mathrm{H}, \mathrm{CH}_{2}\right), 1.90\left(\mathrm{~s}, 3 \mathrm{H}, \mathrm{CH}_{3}\right), 1.94\left(\mathrm{~m}, 4 \mathrm{H}, \mathrm{CH}_{2}\right), 2.17$ (s, 3H, OAc), 2.35 (s, 3H, OAc), 2.44 (d, $\left.4 \mathrm{H}, \mathrm{CH}_{2}, 2 \mathrm{H}, \mathrm{CH}_{2}\right), 2.57$ (m, $\left.2 \mathrm{H}, \mathrm{CH}_{2}\right), 2.72\left(\mathrm{bs}, 2 \mathrm{H}, \mathrm{CH}_{2}\right), 2.84\left(\mathrm{~m}, 4 \mathrm{H}, \mathrm{CH}_{2}\right), 3.16\left(\mathrm{~d}, 2 \mathrm{H}, \mathrm{CH}_{2}\right), 3.50$ $\left(\mathrm{t}, 4 \mathrm{H}, \mathrm{CH}_{2}\right), 3.63\left(\mathrm{bs}, \mathrm{OCH}_{2} \mathrm{CH}_{2}\right), 3.81(\mathrm{~d}, 1 \mathrm{H}, \mathrm{CH}), 4.19\left(\mathrm{~m}, 4 \mathrm{H}, \mathrm{CH}_{2}\right.$, $\left.2 \mathrm{H}, \mathrm{CH}_{2}\right), 4.32(\mathrm{dd}, 1 \mathrm{H}, \mathrm{CH}), 4.82(\mathrm{~d}, 1 \mathrm{H}, \mathrm{CH}), 5.00(\mathrm{~d}, 1 \mathrm{H}, \mathrm{CH}), 5.50$ (d, $1 \mathrm{H}, \mathrm{CH}), 5.64(\mathrm{dd}, 1 \mathrm{H}, \mathrm{CH}), 6.15(\mathrm{t}, 1 \mathrm{H}, \mathrm{CH}), 6.46(\mathrm{~s}, 1 \mathrm{H}, \mathrm{CH}), 6.94$ (d, $1 \mathrm{H}, \mathrm{NH}), 7.26$ (m, aromatic), 7.40 (m, aromatic), 7.52 (m, aromatic), 7.84 (m, aromatic), 8.09 (m, aromatic).

\section{Synthesis of lipoic acid anhydride}

A mixture of lipoic acid $(5.0 \mathrm{~g}, 24.0 \mathrm{mmol})$ and dicyclohexyl carbodiimide ( $3.25 \mathrm{~g}, 16.0 \mathrm{mmol}$ ) was stirred in $30 \mathrm{~mL}$ of dry methylene chloride for overnight at room temperature under argon atmosphere. The product mixture was filtered in order to remove the urea which had formed. The methylene chloride was removed under reduced pressure to afford a yellow solid. Lipoic acid anhydride was used without further purification.Examination of the filtrate by IR revealed the presence of lipoic acid anhydride (1746 and $\left.1817 \mathrm{~cm}^{-1}\right)$.

IR (KBr): 1817(s), 1746(s) $\mathrm{cm}^{-1}$

\section{Synthesis of poly (AMPD-BAC)-g-PEG-lipoly-PTX}

To a poly(AMPD-BAC)-g-PEG-PTX (1.5g, 0.16mmol) in $30 \mathrm{~mL}$ dry methylene chloride was added lipoic acid anhydride $(0.25 \mathrm{~g}, 0.64$ $\mathrm{mmol}$ ) and 4-(dimethylamino)pyridine $(0.1 \mathrm{mg}, 0.81 \mathrm{mmol})$. After the mixture wasstirred for $24 \mathrm{~h}$ under argon at room temperature, the resulted solution was dialyzed against methanol for five times. The solvent was removed under reduced pressure to afford poly(AMPDBAC)-g-PEG-lipoly-PTX a light yellow solid.

Yield $=0.80 \mathrm{~g}(50 \%)$

${ }^{1} \mathrm{H} \mathrm{NMR}(\mathrm{CDCl} 3): \delta 1.14\left(\mathrm{~s}, 3 \mathrm{H}, \mathrm{CH}_{3}\right), 1.24\left(\mathrm{~m}, 2 \mathrm{H}, \mathrm{CH}_{2}\right), 2.23(\mathrm{~s}, 3 \mathrm{H}$, $\mathrm{OAc}), 2.38$ (s, 3H, OAc), $2.57\left(\mathrm{~m}, 4 \mathrm{H}, \mathrm{CH}_{2}, 2 \mathrm{H}, \mathrm{CH}_{2}, 2 \mathrm{H}, \mathrm{CH}_{2}\right), 2.78(\mathrm{~m}$, $\left.2 \mathrm{H}, \mathrm{CH}_{2}, 4 \mathrm{H}, \mathrm{CH}_{2}\right), 2.90\left(\mathrm{~d}, 2 \mathrm{H}, \mathrm{CH}_{2}\right), 3.10\left(\mathrm{~m}, 4 \mathrm{H}\right.$, lipoic-CH $\mathrm{CHS}_{2}, 3.64$ (bs, $\left.\mathrm{OCH}_{2} \mathrm{CH}_{2}\right), 3.80(\mathrm{~d}, 1 \mathrm{H}, \mathrm{CH}), 4.16\left(\mathrm{~m}, 4 \mathrm{H}, \mathrm{CH}_{2}, 2 \mathrm{H}, \mathrm{CH}_{2}\right), 4.39(\mathrm{dd}$, $1 \mathrm{H}, \mathrm{CH}), 4.80(\mathrm{~d}, 1 \mathrm{H}, \mathrm{CH}), 4.92(\mathrm{~d}, 1 \mathrm{H}, \mathrm{CH}), 5.66(\mathrm{~d}, 1 \mathrm{H}, \mathrm{CH}), 5.77(\mathrm{dd}$, $1 \mathrm{H}, \mathrm{CH}), 6.23(\mathrm{t}, 1 \mathrm{H}, \mathrm{CH}), 6.80(\mathrm{~d}, 1 \mathrm{H}, \mathrm{NH}), 7.24(\mathrm{~m}$, aromatic), 7.40 (m, aromatic), 7.47 (m, aromatic), $7.74(\mathrm{~m}$, aromatic), 8.13 (m, aromatic).

\section{Synthesis of poly(AMPD-BAC)-g-PEG-lipoyl-PTX-MMP2 peptide}

MMP-2 sensitive peptide (100 $\mathrm{mg}, 0.093 \mathrm{mmol}$ ) was dissolved in $20 \mathrm{~mL}$ dry DMSO. Subsequently, acrylic acid N-hydroxy succinimide ester $(100 \mathrm{mg}, 0.6 \mathrm{mmol})$ and triethylamine $(0.1 \mathrm{~mL}, 1 \mathrm{mmol})$ were added. The resultant solution was stirred for $24 \mathrm{~h}$ at room temperature. Acrylate MMP-2 sensitive peptide was precipitated from the solution by diethyl ether. The peptide was collected and used without further purification. To a micellar solution of poly(AMPD-BAC)-g-PEG-lipoylPTX $(1.5 \mathrm{~g}, 0.16 \mathrm{mmol})$ in $30 \mathrm{~mL}$ DI water was added acrylate MMP-2 sensitive peptide $(0.1 \mathrm{~g}, 0.1 \mathrm{mmol})$. After the mixture wasstirred for 48 $\mathrm{h}$ under argon at $50^{\circ} \mathrm{C}$, the resulted solution was dialyzed against water for five times and then freeze drying to afford poly(AMPD-BAC)-gPEG- lipoyl-PTX-MMP2 a light yellow solid.

Yield $=0.90 \mathrm{~g}(54 \%)$

${ }^{1} \mathrm{H}$ NMR (MeOD): $\delta 0.9-0.98$ (val/leu mmp2), $1.14\left(\mathrm{~m}, 3 \mathrm{H}, \mathrm{CH}_{3}\right)$, $1.34\left(\mathrm{~m}, 2 \mathrm{H}, \mathrm{CH}_{2}\right), 1.68\left(\mathrm{~s}, 3 \mathrm{H}, \mathrm{CH}_{3}\right), 1.83\left(\mathrm{~m}, 3 \mathrm{H}, \mathrm{CH}_{3}\right), 1.96(\mathrm{~m}, 4 \mathrm{H}$, $\left.\mathrm{CH}_{2}\right), 2.16(\mathrm{~s}, 3 \mathrm{H}, \mathrm{OAc}), 2.35(\mathrm{~s}, 3 \mathrm{H}, \mathrm{OAc}), 2.45\left(\mathrm{~d}, 4 \mathrm{H}, \mathrm{CH}_{2}\right), 2.59(\mathrm{~m}$, $\left.2 \mathrm{H}, \mathrm{CH}_{2}\right), 2.75\left(\mathrm{~m}, 2 \mathrm{H}, \mathrm{CH}_{2}\right), 2.84\left(\mathrm{~m}, 2 \mathrm{H}, \mathrm{CH}_{2}\right), 3.04(\mathrm{~m}, \mathrm{mmp} 2), 3.16$ (d, $2 \mathrm{H}, \mathrm{CH}_{2}$ ), 3.50 (bs, $4 \mathrm{H}, \mathrm{CH}_{2}$ ), 3.64 (bs, $\mathrm{OCH}_{2} \mathrm{CH}_{2}$ ), $3.80(\mathrm{~d}, 1 \mathrm{H}, \mathrm{CH}$ ), $4.18\left(\mathrm{~m}, 4 \mathrm{H}, \mathrm{CH}_{2}, 2 \mathrm{H}, \mathrm{CH}_{2}\right), 4.29(\mathrm{dd}, 1 \mathrm{H}, \mathrm{CH}), 4.40(\mathrm{~m}, \mathrm{mmp} 2), 5.43$ (d, $1 \mathrm{H}, \mathrm{CH}), 5.64(\mathrm{dd}, 1 \mathrm{H}, \mathrm{CH}), 6.15(\mathrm{t}, 1 \mathrm{H}, \mathrm{CH}), 6.78(\mathrm{~s}, 1 \mathrm{H}, \mathrm{CH}), 7.45-$ 8.23 (m, aromatic).

\section{Preparation of crosslinked micelles}

The poly (AMPD-BAC)-g-PEG-lipoyl-PTX was dissolved in water at $\mathrm{pH} 2.0$, and the solution was adjusted to $\mathrm{pH} 8.0$ to induce the formation of micelles. The solution was stirred in air for $48 \mathrm{~h}$ with small amount of $\mathrm{H}_{2} \mathrm{O}_{2}$. The cross linking of lipoic acid was confirmed by ultraviolent measurement.

\section{Determination of loading and encapsulation of PTX}

To determine the loading of PTX in polymer system, micelle was dissolved with acetonitrile. The solution was analysed for PTX content using HPLC. Varian prostar 210 HPLC system at a flow rate of $1.0 \mathrm{~mL} /$ min at room temperature was used. The detection was performed at $227 \mathrm{~nm}$ using a Varian Photodiode Array HPLC detector. A $20 \mu \mathrm{L}$ of sample was injected in a gradient elution using $0.1 \%$ trifluroacetic acid aqueous solution and acetonitrile. The level of PTX loading (w/w\%), and encapsulation efficiency were calculated using the following Eqs:

PTX loading $(\mathrm{w} / \mathrm{w} \%)=($ Amount of detected PTX in $\mathrm{mg} /$ Amount of copolymer in $\mathrm{mg}) \times 100$

Encapsulation efficiency $(\%)=($ Amount of detected PTX in mg $/$ Amount of PTX added in $\mathrm{mg}) \times 100$

\section{Reduction-triggered destabilization of poly(AMPD-BAC)-g- PEG-lipoyl-PTX micelles}

The size change of micelles in response to $20 \mu \mathrm{M}$ DTT was followed by DLS measurement. In detail, $1 \mathrm{mg} / \mathrm{mL}$ of poly(AMPD-BAC)-gPEG-lipoly-PTX micelles in water was added with $20 \mu \mathrm{M}$ DTT. The solution was placed on a shaking bed with a rotation speed of $200 \mathrm{rpm}$.

\section{Reduction and MMP2 enzyme triggered destabilization of poly(AMPD-BAC)-g-PEG-lipoyl-PTX-MMP2 micelles}

All dynamic light scattering experiments were performed in $1 \mathrm{~mL}$ solutions of $0.1 \mathrm{M}$ HEPES $0.15 \mathrm{M} \mathrm{NaCl} 0.005 \mathrm{M} \mathrm{CaCl} 2$ with $0.5 \mathrm{mg} / \mathrm{mL}$ polymer. To begin experiment, catalytic domains of MMP2 $(3.0 \mu \mathrm{g})$ and DTT $(20 \mu \mathrm{M})$ were added in $1 \mathrm{~mL}$ of polymer. The degradation of polymer was also examined in the absence of catalytic domain of MMP2. Kinetic dynamic light scattering intensity size measurements were taken and hydrodynamic radius was plotted vs. time.

\section{Preparation of FITC labeledpoly(AMPD-BAC)-g-PEG- lipoyl-PTX-MMP2}

FITC is attached to poly(AMPD-BAC)-g-PEG-lipoyl-PTX-MMP2 via the reaction between isothiocyanate groups of FITC and the residual amines on poly(AMPD-BAC)-g-PEG-lipoyl-PTX-MMP2. In a typical process, $0.1 \mathrm{~g}$ of poly(AMPD-BAC)-g-PEG-lipoyl-PTXMMP2was dissolved in $4 \mathrm{~mL}$ of dried DMSO. Subsequently, a solution of $70 \mathrm{mg}$ of FITC in $2 \mathrm{~mL}$ of DMSO was added dropwise. The reaction was performed in dark at ambient temperature overnight. The solution was dialyzed in methanol for five times.

\section{Cytotoxicity assay}

MCF-10A and MDA-MB-231 cells were cultured in DMEM supplemented with $10 \% \mathrm{FBS}$ at $37^{\circ} \mathrm{C}, 10 \% \mathrm{CO}_{2}$, and $95 \%$ relative humidity. For the cell viability assay, polymer solutions were prepared 
in serum supplemented tissue culture medium. The cells $(10,000$ cells/ well) were seeded into 96-well microtiter plates (Nunc, Wiesbaden, Germany). After overnight incubation, the culture medium was replaced with $100 \mu \mathrm{L}$ of serial dilutions of the polymers, and the cells were incubated for 24 and 48 hours. Twenty microlitre of sterile filtered MTT (3-(4,5-dimethylthiazol-2-yl)-2,5-diphenyl tetrazolium bromide) $\left(5 \mathrm{mgmL}^{-1}\right)$ stock solution in phosphate buffered saline (PBS) was added to each well. After 4 hours, unreacted dye was removed by aspiration. The formazan crystals were dissolved in $100 \mu \mathrm{L} /$ well DMSO (BDH laboratory Supplies, England) and measured spectrophotometrically in an ELISA reader (Model 550, Bio-Rad) at a wavelength of $570 \mathrm{~nm}$. The spectrophotometer was calibrated to zero absorbance using culture medium without cells. The relative cell growth (\%) related to control cells containing cell culture medium without polymer was calculated by $[\mathrm{A}]$ test $/[\mathrm{A}]$ control $\times 100 \%$. All tests were performed in triplicates.

\section{Annexin $\mathrm{V}$ and propidium iodide staining for flow cytometry}

The percentage of cells actively undergoing apoptosis was

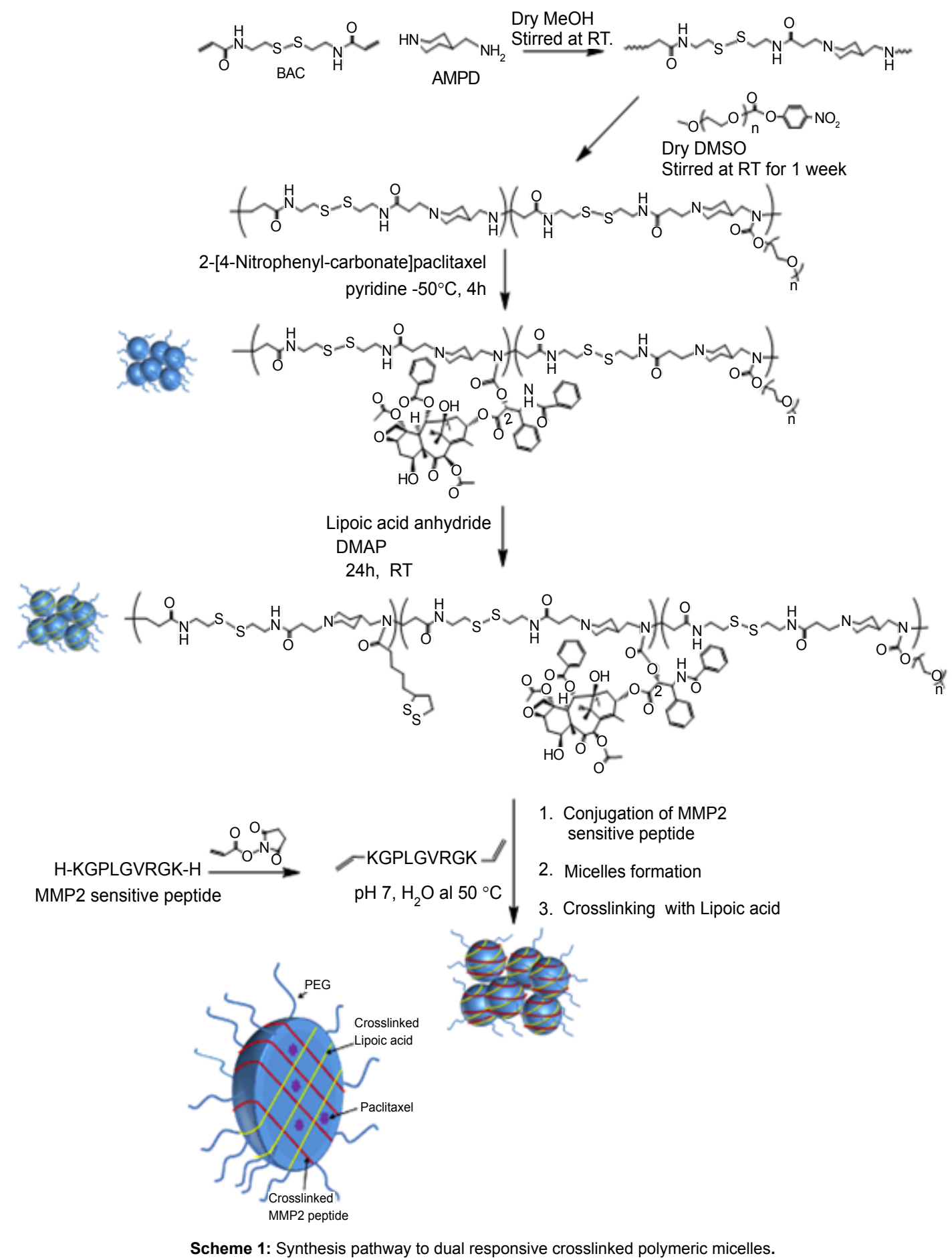


determined using annexin V-PE-based immunofluorescence, as described previously. Briefly, MDA-MB-231 cells were plated in 6-well flat bottom plates to yield $80 \%$ confluence within $24 \mathrm{~h}$. They were then treated with polymer and incubated for $24 \mathrm{~h}$, after which the cells were harvested and then double-labelled with annexin V-FITC and PI, as described by the manufacturer (BD Biosciences). The cells were then analyzed by flow cytometry.

\section{Cell cycle by flow cytometry}

Cells were plated in 6-well flat bottom plates with $80 \%$ confluence after $24 \mathrm{~h}$. They were treated with indicated concentration of the osmium carbonyl clusters for $24 \mathrm{~h}$ then trypsinized and washed twice with cold PBS, resuspended in $70 \%$ ethanol and then incubated at room temperature for $30 \mathrm{~min}$. After this, they were spun down at $2000 \mathrm{rpm}$ (400 g) for $5 \mathrm{~min}$, washed once, and re-suspended again with $1 \mathrm{x}$ PBS containing $1 \% \mathrm{FBS}(500 \mu \mathrm{L})$. This was then incubated $\left(37^{\circ} \mathrm{C}\right.$ for $\left.15 \mathrm{~min}\right)$ after the addition of $1 \times$ RNase $(20 \mu \mathrm{L})$, after which $1 \times$ PI $(50 \mu \mathrm{L})$ was added, and the samples analyzed by flow cytometry within $1 \mathrm{~h}$.

\section{In-Vitro fluorescence confocal imaging of poly (AMPD-BAC)- g-PEG-lipoyl-PTX-MMP2uptake}

Cells were grown on coverslips (60\% confluence), incubated with solution of FITC labelled poly(AMPD-BAC)-g-PEG-lipoylPTX-MMP2 for $24 \mathrm{~h}$, washed with $1 \times$ PBS $(3 \times 2 \mathrm{~mL})$, fixed with $5 \%$ formaldehyde in PBS for $20 \mathrm{~min}$ at room temperature. They were then permeabilized with $0.1 \%$ Triton X-10 in PBS (USB Corp). The sample was then washed with $1 \times$ PBS $(3 \times 3 \mathrm{~mL})$, mounted with $200 \mu$ DAPI containing Pro Long Gold antifade reagent (Invitrogen). Laser confocal fluorescence micrographs were obtained on a Leica TCS SP5X. For DAPI imaging, the emission was observed at $421 \mathrm{~nm}$ with an excitation at $401 \mathrm{~nm}$; and for FITC imaging, the emission was observed at $517 \mathrm{~nm}$ with an excitation $495 \mathrm{~nm}$ (Scheme 1).

\section{Results and Discussion}

The redox-responsive poly(AMPD-BAC)-g-PEG was prepared by Michael-addition polymerization of diamine (AMPD; 4-aminomethyl piperidine), with an equimolar bisacrylamide (BCA; $N, N^{\prime}$-bis(acryloyl) cystamine). It was reported that amino units in a diamine have different reactivity in Michael-addition polymerization in which the topology of polymers can be tuned simply by varying the molar ratio of diamine to bisacrylamide $[15,54]$. The secondary amines readily react with 4-nitrophenyl carbonate-activated PEG to form PEG-grafted poly (amido amine). The composition of poly(AMPD-BAC)-g-PEG was determined by ${ }^{1} \mathrm{H}-\mathrm{NMR}$ measurement from the peak intensity ratio between the PEG (4.14 ppm) and AMPD-BAC (1.52 ppm) (Figures S1 and S2 of the Supplementary Information). The AMPD-BAC unit number per PEG was five. A vast literature on PEG for drug delivery shows that PEG stealth layers exhibit significantly reduced non-specific adsorption of protein, enabling a longer in vivo circulation duration and passive targeting of cancer cells which consequently improve $d r u g$ delivery efficacy [55-58].

The 2'-[4-nitrophenyl carbonate] paclitaxel (NPC-PTX) was prepared from PTX to conjugate to poly(AMPD-BAC)-g-PEG. The 2-OH group poses less steric hindrance as compared to the $7-\mathrm{OH}$ group of PTX, and it readily reacts with 4-nitrophenyl chloroformate to obtain a carbonate derivative reactive towards secondary amine groups of poly(AMPD-BAC)-g-PEG [52,53] (Figure S3 of the supplementary information). The presence of PTX peaks (phenyl proton signal at $\sim 7.3-8.3 \mathrm{ppm}$ ) confirmed the binding of PTX to polymer (Figure S4 of the supplementary information). To determine the loading of PTX in micelles, the micelle solution was dissolve with acetonitrile. The solution was analysed for PTX content using HPLC. The level of PTX loading $(\mathrm{w} / \mathrm{w} \%)$ and encapsulation efficiency were calculated to be 1.9 $\mathrm{wt} \%( \pm 0.23 \%)$ and $26.0 \%( \pm 0.23 \%)$, respectively.

The subsequent reaction of lipoic acid anhydride with remaining secondary amines of poly (AMPD-BAC)-g-PEG in the presence of DMAP in $\mathrm{CH}_{2} \mathrm{Cl}_{2}$ leads to a poly (AMPD-BAC)-g-PEG functionalized with lipoic acid. The conjugation of lipoyl units was determined by the observation of a signal at $\delta 3.1 \mathrm{ppm}$ for methylene proton next to the disulfide bond of lipoyl unit. The composition of poly(AMPD-BAC)-gPEG-lipoyl-PTX was estimated from the peak intensity ratio between the lipoyl unit (3.1 ppm) and AMPD-BAC (2.9 ppm) in NMR; each three AMPD-BAC unit was conjugated with approximately one lipoyl unit (Figure S5 and Figure S6 of the Supplementary Information).

Polymer comprising of hydrophilicity-hydrophobicity segment is known to form micelles in aqueous media. In poly(AMPD-BAC)g-PEG-lipoyl-PTX, PTX molecules bind to the hydrophobic part (AMPD unit) of polymer chain and readily assembles to polymeric nanoparticles. Due to the hydrophobicity of PTX, it is expected that PTX is encapsulated within the hydrophobic core of polymeric nanoparticles. A similar approach has also been reported to use for delivery of PTX with poly(ethylene oxide)-b-poly(caprolactone) that can protect PTX within the hydrophobic core of polymeric nanoparticles [59]. Crosslinked poly (AMPD-BAC)-g-PEG-lipoyl-PTX forms micelles with $124.2 \mathrm{~nm}$ average hydrodynamic diameter as determined by DLS (Figure 1). TEM was used to visualize the shape of particles. As can be readily observed, the average diameter of the spherical particles was 90 $\mathrm{nm}$ (Figure 2a). The crosslink between lipoyl units has been exploited to improve the stability of micelles. The disappearance of UV absorbance of lipoic rings at $330 \mathrm{~nm}$ as shown in Figure 3 suggested micelles had been successfully crosslinked in the presence of small amount of $\mathrm{H}_{2} \mathrm{O}_{2}$.

Its average size was $167.4 \mathrm{~nm}$ as determined by DLS as shown in

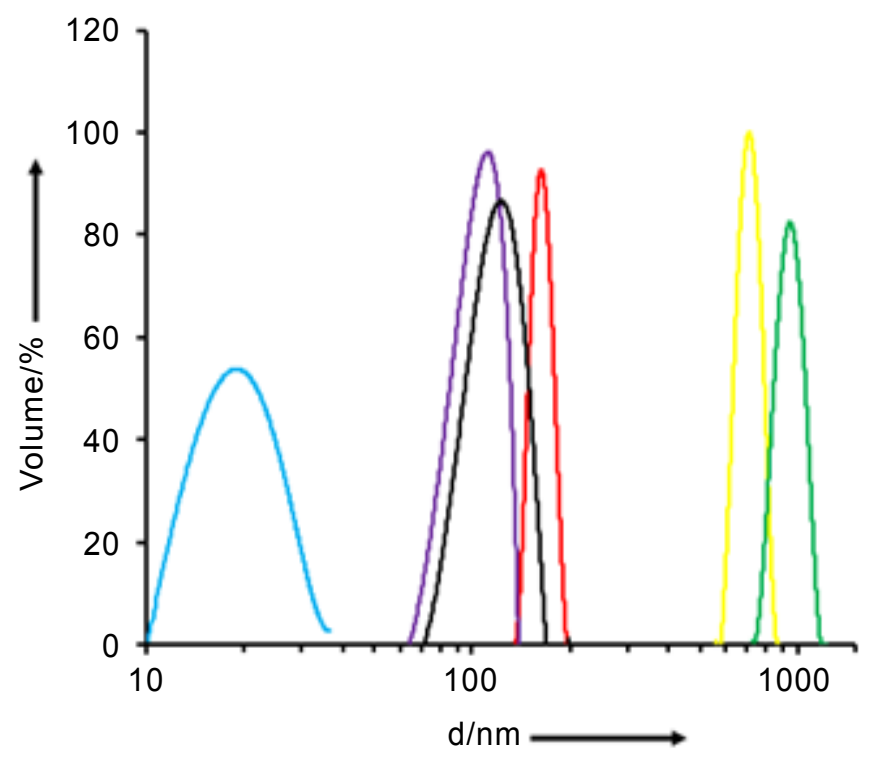

Figure 1: Particles size of polymeric micelles as monitored by DLS. poly(AMPD-BAC)-g-PEG-PTX, crosslinked poly(AMPD-BAC)-g-PEG lipoyl-PTX 10 times dilution of poly(AMPD-BAC)-g-PEG-PTX 10 times dilution of crosslinked poly(AMPD-BAC)-g-PEG-lipovl-PTX poly(AMPD-BAC)-g-PEG-PTX incubated with DTT and $=$ crosslinked poly(AMPD-BAC)-g-PEG-lipoyl-PTX incubated with DTT. 

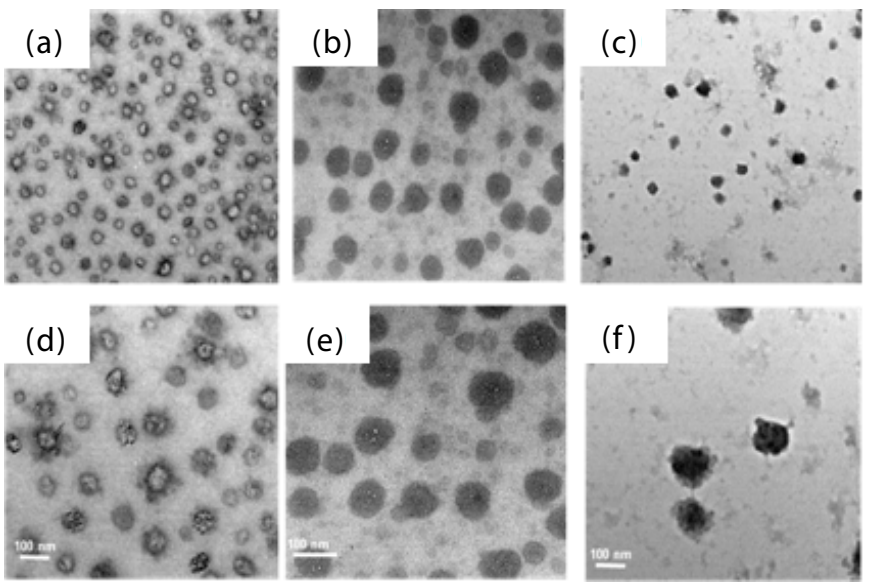

Figure 2: TEM image of (a) poly(AMPD-BAC)-g-PEG-PTX, (b) crosslinked poly(AMPD-BAC)-g-PEG-lipoyl-PTX and (c) crosslinked poly(AMPD-BAC)-gPEG-lipoyl-PTX-MMP2 peptide. (d)-(f) are magnified images of (a) - (c).

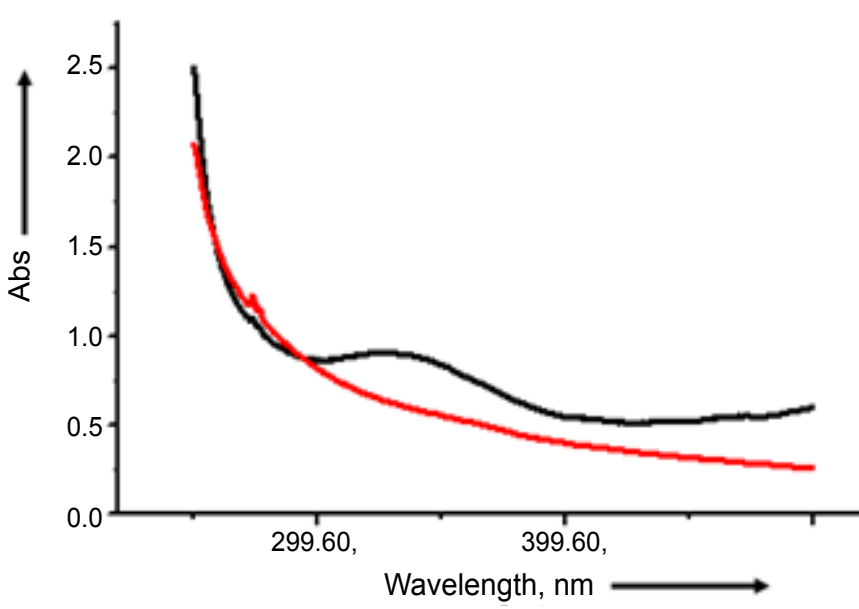

Figure 3: UV spectral changes of crosslinked micelles. uncrosslinked Poly(AMPD-BAC)-g-PEG-lipoyl-PTX and crosslinked Poly(AMPDBAC)-g-PEG-lipoyl-PTX.

Figure 1. The morphology of crosslinked micelles determined by TEM clearly showed that these crosslinked micelles were spherical (Figure $2 \mathrm{~b})$. It is expected that crosslinked poly(AMPD-BAC)-g-PEG-lipoylPTX would be more resistant to dissociation induced by extensive dilution. The stability of micelles was examined by monitoring the changes in the size of micelles after 10 fold dilution. The changes in size of crosslinked micelles from $167.4 \mathrm{~nm}$ to $121.5 \mathrm{~nm}$ were relatively mild compared to its parent micelles from $124.2 \mathrm{~nm}$ to $19 \mathrm{~nm}$, thus demonstrating that via crosslink, the stability of micelles is improved (Figure 1). These stable crosslinked micelles are eventually expected to dissociate through reductive degradation. Its degradation process was monitored by DLS in the presence of DTT. The results showed that the micelles size increased from $167.4 \mathrm{~nm}$ to $907.48 \mathrm{~nm}$. The aggregation of micelle may be attributed to the detachment of PEG chains and subsequently changes the hydrophilicity-hydrophobicity equilibrium of micelles [60]. However, this redox-degradation is not specific because there is a chance of degradation of these stable micelles during delivery due to the presence of reducing agent in the blood stream. We improved the specificity of the degradation process of redox-responsive micelles by adding non-redox responsive crosslinker to micelles to reduce dissociation of micelles in the presence of reducing agents (e.g. DTT, GSH.). Here, MMP-2-sensitive peptide acts as a stabilizer in the event that redox responsive backbone or crosslinker is degraded in a reductive environment. Therefore, the drug release is still in minimal amount in the absence of MMP-2 enzyme in which the real release of drugs by degradation of micelles could be catalyzed only in the presence of both MMP-2 enzyme and reducing agent.

Acrylated MMP-2 sensitive peptide was prepared through the reaction between primary amine of lysine in MMP-2 sensitive peptide and the $N$-hydroxy succinimide ester of acrylic acid $N$-hydroxy succinimide ester under mild condition. The NMR spectrum shows the characteristic proton of vinyl groups; ca. 5.6-6.4 ppm (Figure S7 of the Supplementary Information). MMP-2-sensitive peptideshielded micelles were afforded through the Michael addition reaction of acrylate MMP-2-sensitive peptide with secondary amine groups of micelles. The successful conjugation of MMP-2-sensitive peptide was ascertained by comparing the ${ }^{1} \mathrm{H}$ NMR spectra of poly(AMPD-BAC)g-PEG-lipoyl-PTX to that of poly(AMPD-BAC)-g-PEG-lipoyl-PTXMMP2 peptide, where characteristic peaks of MMP-2 peptide substrate were observed; in the spectrum of poly(AMPD-BAC)-g-PEG-lipoylPTX-MMP2 peptide, the appearance of the $0.91 \mathrm{ppm}$ which is observed in the spectrum of MMP-2 peptide substrate confirmed the conjugation reaction (Figure S8 of the Supplementary Information).

The average hydrodynamic diameter of poly(AMPD-BAC)-g-PEGlipoyl-PTX-MMP2 formed micelles was $158 \mathrm{~nm}$ as determined by DLS. To visualize the shape of the micelles, TEM images were obtained. From the TEM, spherical micelles were observed with an average diameter of $140 \mathrm{~nm}$ which is consistent with the DLS result (Figure 2c). The effect of MMP-2 sensitive peptide on PTX release was monitored by DLS over 80 mins in the presence of MMP-2 catalytic domains or DTT in PBS (Figure 4). In the presence of DTT alone, the PTX release of MMP-2 crosslinked micelles was significantly decreased by $40 \%$ compared to its micelles without MMP-2 peptide as crosslinker, thus demonstrating that the stability of micelles to DTT is improved. These stable MMP-2 crosslinked micelles were easy to dissociate through MMP-2 enzyme clevage and DTT reductive degradation. The results showed that in

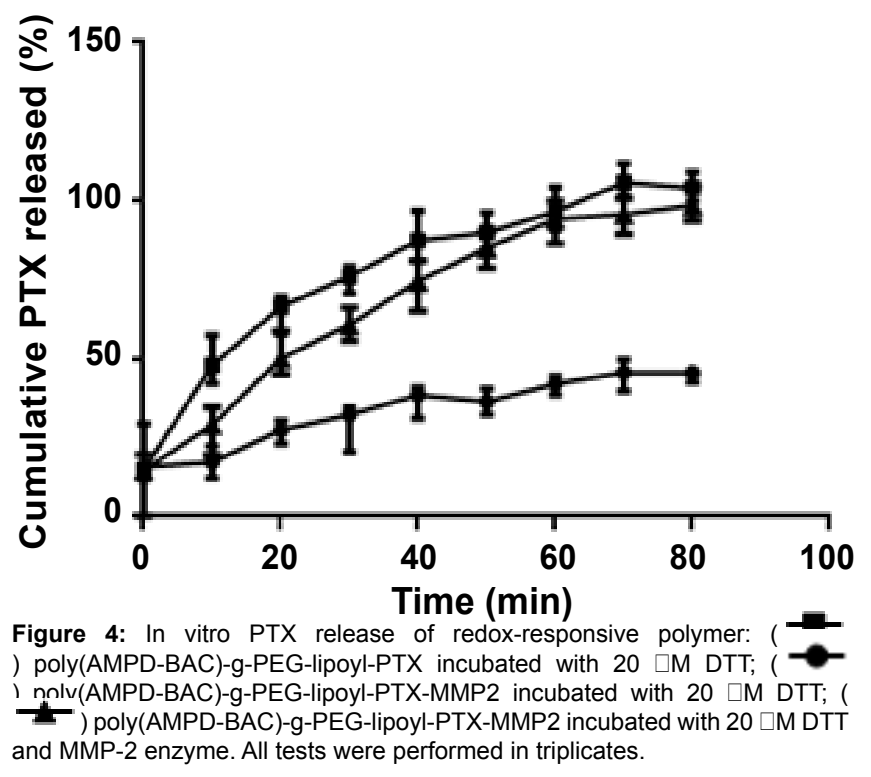


Citation: Kong KV, Goh D, Olivo M (2014) Dual Trigger Crosslinked Micelles Based Polyamidoamine for Effective Paclitaxel Delivery. J Nanomed Nanotechnol 5: 212. doi: 10.4172/2157-7439.1000212

the presence of MMP-2 and DTT, the PTX release was increased.The decreased of PTX release in the absence of MMP-2 is caused by micelles stabilised by MMP-2 sensitive peptide, whereas the greater PTX release was observed in the presence of MMP-2. This indicated that the PTX release could be controlled by the incorporation of MMP2 sensitive peptide crosslinker. Such variation in the PTX release can be exploited to improve the delivery of therapeutic agents.

The cytotoxicity of MMP-2 crosslinked micelles was determined by MTT assay for cell proliferation activity against two cell lines, viz., breast carcinoma (MDA-MB-231) and a normal breast epithelial cell line (MCF-10A). MDA-MB-231 is reported to highly express MMP-2 enzyme [61-64]. Both crosslinked poly(AMPD-BAC)-gPEG-lipoyl-PTX and poly(AMPD-BAC)-g-PEG-lipoyl-PTX-MMP2 micelles showed appreciable cytotoxicity for MDA-MB-231 (IC50 for poly(AMPD-BAC)-g-PEG-lipoyl-PTX and poly(AMPD-BAC)g-PEG-lipoyl-PTX-MMP2 are $5.79 \mu \mathrm{M}$ and $8.65 \mu \mathrm{M}$, respectively), whereas crosslinked poly(AMPD-BAC)-g-PEG-lipoyl-PTX micelles showed little selectivity; poly(AMPD-BAC)-g-PEG-lipoyl-PTX-MMP2 micelles showed significantly different cytotoxicity with the normal epithelium cell line (Figure 5) (IC50 for poly(AMPD-BAC)-g-PEGlipoyl-PTX and poly(AMPD-BAC)-g-PEG-lipoyl-PTX-MMP2 are 9.79 $\mu \mathrm{M}$ and $17.25 \mu \mathrm{M}$, respectively). These results were also reflected in the morphological changes of the cells (Figure 6); poly (AMPD-BAC)-gPEG-lipoyl-PTX caused significant morphological changes and cells number reduced for both MDA-MB-231 and MCF-10A, whereas MMP-2 crosslinked micelles significantly affected MDA-MB-231 and not MCF-10A. This is consistent with the induction of apoptosis. Flow cytometry using FITC-conjugated annexin $\mathrm{V}$ and propidium iodide staining showed that early and late apoptosis cell population (FITC stained) was increased from $7.89 \%$ to $15.72 \%$ and $8.83 \%$ to $16.87 \%$ in the presence of MMP-2 enzyme (Figure 7). Flow cytometric analysis for DNA fragmentation also exhibits greater cell cycle arrest at the G2 phase in the presence of MMP-2 enzyme; $49.64 \%$ compared to $31.60 \%$ and $28.40 \%$ for the absence of MMP-2 enzyme and control, respectively. PTX is known to show $S$ phase cell cycle arrest [65] (Figure 8). The efficacy of crosslinked poly (AMPD-BAC)-g-PEG-lipoyl-PTX-MMP2 micelles was particularly interesting. A possible reason may be that in

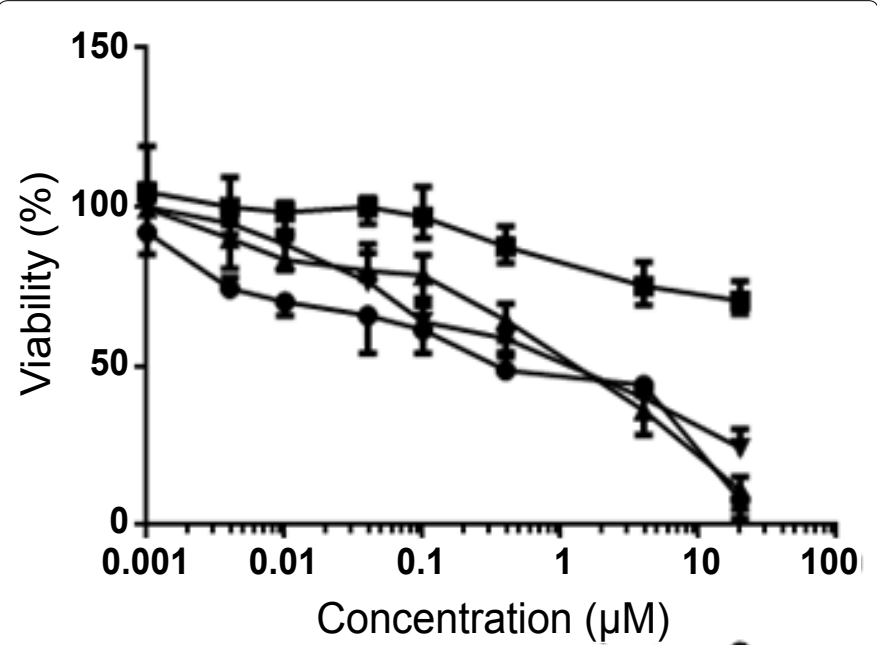

Figure 5: Effects of poly(AMPD-BAC)-g-PEG-lipoyl-PTX in (-) MDAMB-231 and (-) MCF-10A ard noly(AMPD-BAC)-g-PEG-lipoyl-PTX-MMP2 in (-) MDA-MB-231 and (-) MCF-10A after $24 \mathrm{~h}$ incubation. The concentration in $\mathrm{X}$-axis refers to that of PTX in the system or in micelles. The concentration of PTX in micelles system is calculated based on the wt $\%$ of PTX in a polymer system. All tests were performed in triplicates.
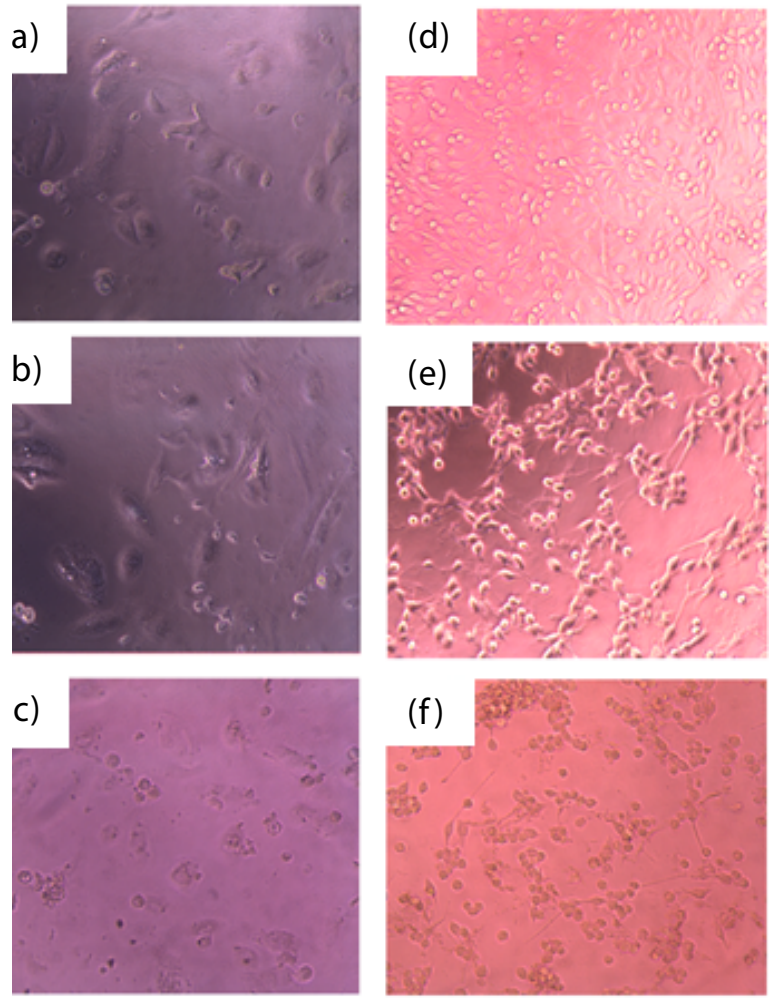

Figure 6: Optical images of (upper) MCF-10A and (bottom) MDA-MB-231 cells. Poly(AMPD-BAC)-g-PEG-lipoyl-PTX (b \& e) and poly(AMPD-BAC)-gPEG-lipoyl-PTX-MMP2 (c \& f) treated MDA-MB-231 and MCF-10A cells. (a) and $(d)$ are untreated cells.
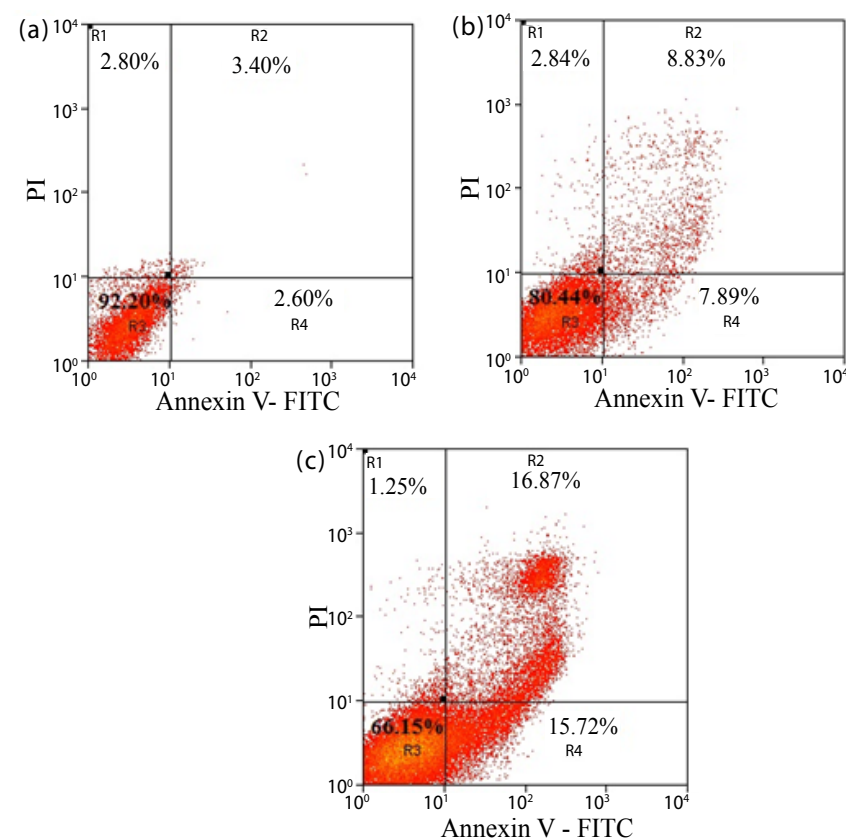

Figure 7: Detection of early and late apoptosis MDA-MB-231 cells after staining woth annexin V-FITC and PI. Cells were incubated with (a) poly(AMPD-BAC)g-PEG, (b) poly(AMPD-BAC)-g-PEG-lipoyl-PTX-MMP2 and DTT, and (c) poly(AMPD-BAC)-g-PEG-lipoyl-PTX-MMP2, DTT and MMP-2 enzyme. All tests were performed in triplicates. 
Citation: Kong KV, Goh D, Olivo M (2014) Dual Trigger Crosslinked Micelles Based Polyamidoamine for Effective Paclitaxel Delivery. J Nanomed Nanotechnol 5: 212. doi: 10.4172/2157-7439.1000212
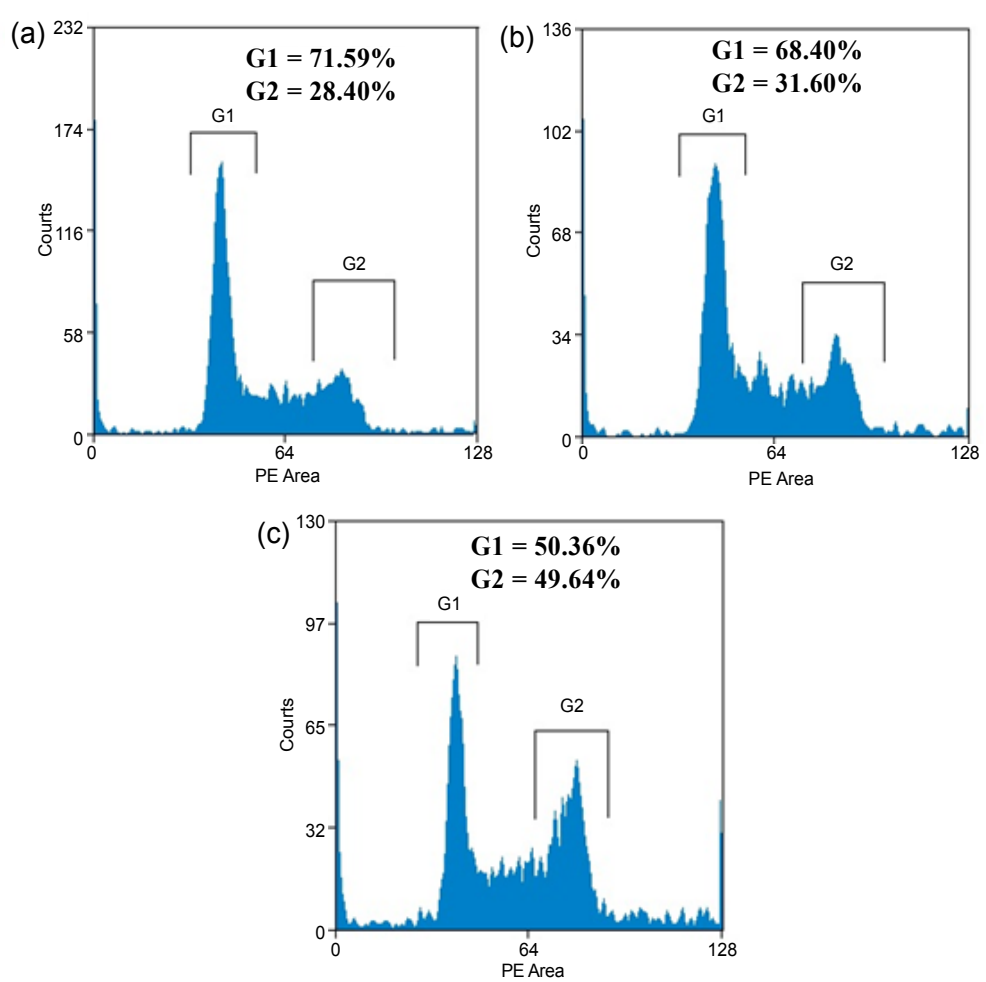

Figure 8: Cellular DNA content analysis of MDA-MB-231 cells after incubation with (a) poly(AMPD-BAC)-g-PEG, (b) poly(AMPD-BAC)-g-PEG-lipoyl-PTX-MMP2 and DTT, and (c) poly(AMPD-BAC)-g-PEG-lipoyl-PTX-MMP2, DTT and MMP-2 enzyme. All tests were performed in triplicates.
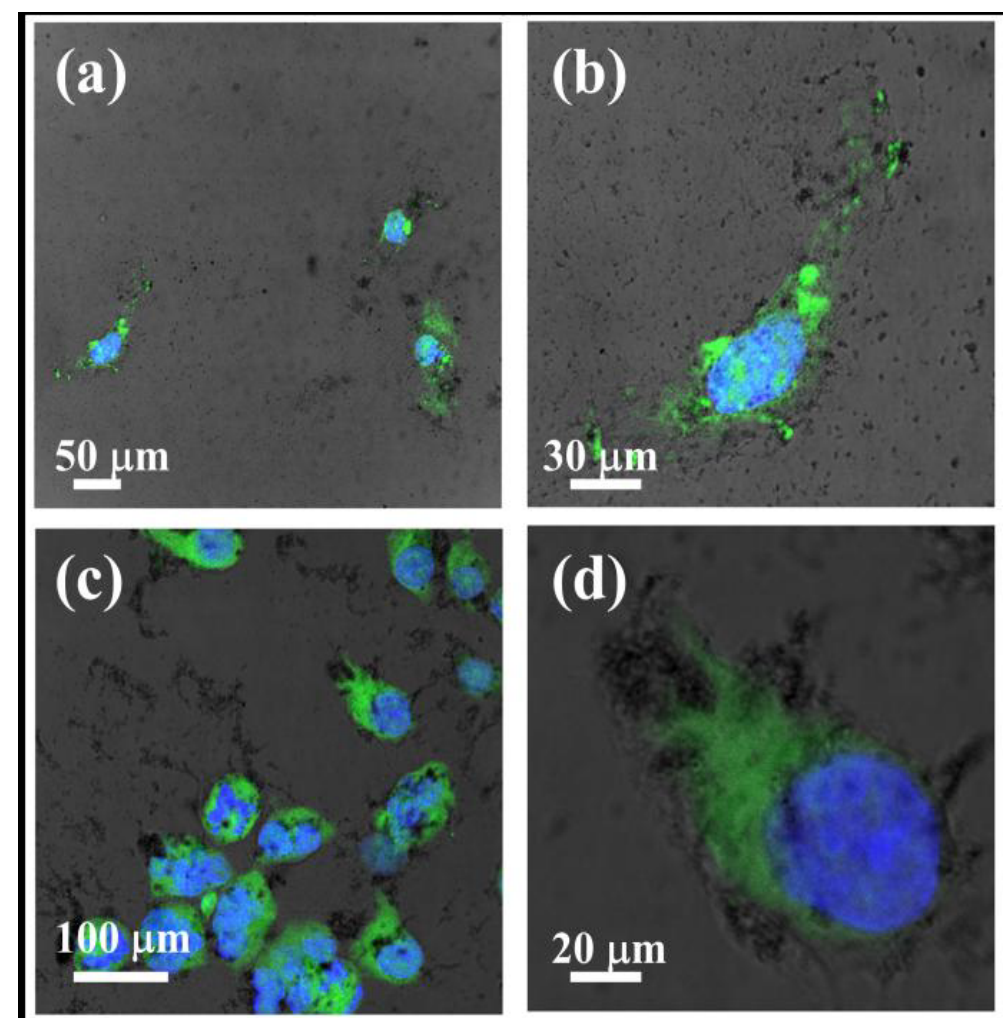

Figure 9: Fluorescence microscopic images of (a) MCF-10A and (c) MDA-MB-231 cells incubated with FITC-labelled poly(AMPD-BAC)-g-PEG-lipoyl-PTX-MMP2 (green) for $24 \mathrm{~h}$, and stained with DAPI (blue) stains helped localized the cell nuclei. (c) and (d) are magnified images of cell in white box of (a) and (c). 
MDA-MB-231, the MMP-2 sensitive peptide was cleaved by MMP-2, and the degradation of micelles was subsequently accelerated by redox degradation. This is alluded by the degradation study, which showed that the degradation rate of crosslinked poly (AMPD-BAC)-g-PEGlipoyl-PTX-MMP2 micelles in the presence of MMP-2 was increased.

The interaction of crosslinked poly (AMPD-BAC)-g-PEG-lipoylPTX-MMP2 micelles with cells was confirmed through visualisation via fluorescence confocal microscopy using FITC-labelled crosslinked poly (AMPD-BAC)-g-PEG-lipoyl-PTX-MMP2 micelles. We found that both MCF-10A and MDA-MB-231 cells showed strong fluorescence as shown in Figure 9, suggesting that poly (AMPD-BAC)-g-PEG-lipoylPTX-MMP2 micelles can be easily transported into cells and amount of uptake of micelles is not the critical part for the selectivity of micelles to cancer cells. In fact, the drug release by degradation process inside cells is critical. Although the amount of micelles being uptaken is not significantly different in both scenarios, the rate of degradation is expected to be different. The reason is that due to the presence of MMP2 enzyme in extracellular and intracellular of cancer cells, the MMP2 crosslinker of micelles is removed, and the subsequent exposure of GSH accelerates the degradation of micelles which in turn induces a high concentration of PTX being release inside a cancer cell.

On the other hand, the MMP-2 crosslinker is expected to keep the micelles binded together in normal cells where MMP2 enzyme expression is low, and thus there would be a subsequently slower PTX release even in the presence of GSH. This explanation is in line with the micelles degradation, cytotoxicity studies and fluorescence imaging results. The increased activity of drug release in cancer cell points us in the direction to potentially overcome non-specificity issues and premature drug release, by stabilized redox-responsive micelles with MMP-2.

\section{Conclusion}

In conclusion, we developed a specific degradation system. The reactivity of secondary amines of poly (amidoamine) s was utilized to conjugate poly (ethylene)glycol, PTX and MMP-2 sensitive peptide. The MMP-2 sensitive peptide crosslinked micelles were expected to show improved stability even in the presence of reducing agents, but rapidly dissociated in the presence of both MMP-2 enzyme and reducing agents. This work serves to illustrate that varied degradation rate of redox-responsive micelles is possible, and such a variation in the degradation rate may be exploited to improve the delivery of therapeutic agents.

\section{Acknowledgements}

This work was supported by the SBIC (Biomedical Research Council, Agency for Science, Technology and Research, Singapore).

\section{References}

1. Hamaguchi T, Matsumura Y, Suzuki M, Shimizu K, Goda R, et al. (2005) NK105 a paclitaxel-incorporating micellar nanoparticle formulation, can extend in vivo antitumour activity and reduce the neurotoxicity of paclitaxel. $\mathrm{Br} \mathrm{J}$ Cancer 92 1240-1246.

2. Kataoka K, Harada A, Nagasaki Y (2001) Block copolymer micelles for drug delivery: design, characterization and biological significance. Adv Drug Deliv Rev 47: 113-131.

3. Lee KS, Chung HC, Im SA, Park YH, Kim CS, et al. (2008) Multicenter phase II trial of Genexol-PM, a Cremophor-free, polymeric micelle formulation of paclitaxel, in patients with metastatic breast cancer. Breast Cancer Res Treat 108: $241-250$.

4. Matsumura Y, Kataoka K (2009) Preclinical and clinical studies of anticancer agent-incorporating polymer micelles. Cancer Sci 100: 572-579.
5. Nishiyama N, Kataoka K (2006) Current state, achievements, and future prospects of polymeric micelles as nanocarriers for drug and gene delivery Pharmacol Ther 112: 630-648.

6. Osada K, Christie RJ, Kataoka K (2009) Polymeric micelles from poly(ethylene glycol)-poly(amino acid) block copolymer for drug and gene delivery. J R Soc Interface 6 Suppl 3: S325-339.

7. Uchino H, Matsumura Y, Negishi T, Koizumi F, Hayashi T, et al. (2005) Cisplatinincorporating polymeric micelles (NC-6004) can reduce nephrotoxicity and neurotoxicity of cisplatin in rats. $\mathrm{Br} \mathrm{J}$ Cancer 93: 678-687.

8. Kommareddy S, Amiji M (2005) Preparation and evaluation of thiol-modified gelatin nanoparticles for intracellular DNA delivery in response to glutathione. Bioconjug Chem 16: 1423-1432.

9. Shenoy DB, Amiji MM (2005) Poly(ethylene oxide)-modified poly(epsiloncaprolactone) nanoparticles for targeted delivery of tamoxifen in breast cancer. Int J Pharm 293: 261-270.

10. Torchilin VP (2007) Targeted pharmaceutical nanocarriers for cancer therapy and imaging. AAPS J 9: E128-147.

11. Owens DE 3rd, Peppas NA (2006) Opsonization, biodistribution, and pharmacokinetics of polymeric nanoparticles. Int J Pharm 307: 93-102.

12. Gilbert HF (1995) Thiol/disulfide exchange equilibria and disulfide bond stability. Methods Enzymol 251: 8-28.

13. Raina S, Missiakas D (1997) Making and breaking disulfide bonds. Annu Rev Microbiol 51: 179-202.

14. Meng F, Hennink WE, Zhong Z (2009) Reduction-sensitive polymers and bioconjugates for biomedical applications. Biomaterials 30: 2180-2198.

15. You YZ, Hong CY, Pan CY (2009) Facile One-Pot Approach for Preparing Dually Responsive Core-Shell Nanostructure. Macromolecules 42: 573-575.

16. Bronich TK, Keifer PA, Shlyakhtenko LS, Kabanov AV (2005) Polymer micelle with cross-linked ionic core. J Am Chem Soc 127: 8236-8237.

17. Read ES, Armes SP (2007) Recent advances in shell cross-linked micelles. Chem Commun (Camb) : 3021-3035

18. Li YT, Lokitz BS, Armes SP, McCormick CL (2006) Synthesis of reversible shell cross-linked micelles for controlled release of bioactive agents. Macromolecules 39: $2726-2728$.

19. Thurmond KB, Kowalewski T, Wooley KL (1996) Water-soluble knedel-like structures: The preparation of shell-cross-linked small particles. J Am Chem Soc 118: 7239-7240.

20. Xu YM, Meng FH, Cheng R, Zhong ZY (2009) Reduction-Sensitive Reversibly Crosslinked Biodegradable Micelles for Triggered Release of Doxorubicin Macromol Biosci 9: 1254-1261.

21. O'Reilly RK, Hawker CJ, Wooley KL (2006) Cross-linked block copolymer micelles: functional nanostructures of great potential and versatility. Chem Soc Rev 35: 1068-1083.

22. Schneider P, Korolenko TA, Busch U (1997) A review of drug-induced lysosomal disorders of the liver in man and laboratory animals. Microsc Res Tech 36: 253275 .

23. Balakirev M, Schoehn G, Chroboczek J (2000) Lipoic acid-derived amphiphiles for redox-controlled DNA delivery. Chem Biol 7: 813-819.

24. Sadownik A, Stefely J, Regen SL (1986) Polymerized liposomes formed under extremely mild conditions. J Am Chem Soc 108: 7789-7791.

25. Stefely J, Markowitz MA, Regen SL (1988) Permeability characteristics of lipid bilayers from lipoic acid-derived phosphatidylcholines. Comparison of monomeric, crosslinked and noncrosslinked polymerized membranes. J Am Chem Soc 110: 7463-7469.

26. Chambers AF, Matrisian LM (1997) Changing views of the role of matrix metalloproteinases in metastasis. J Natl Cancer Inst 89: 1260-1270.

27. Curran S, Murray GI (1999) Matrix metalloproteinases in tumour invasion and metastasis. J Pathol 189: 300-308.

28. Hayasaka A, Suzuki N, Fujimoto N, Iwama S, Fukuyama E, et al. (1996) Elevated plasma levels of matrix metalloproteinase-9 (92-kd type IV collagenase/ gelatinase B) in hepatocellular carcinoma. Hepatology 24: 1058-1062.

29. Hofmann UB, Westphal JR, Van Muijen GN, Ruiter DJ (2000) Matrix metalloproteinases in human melanoma. J Invest Dermatol 115: 337-344. 
Citation: Kong KV, Goh D, Olivo M (2014) Dual Trigger Crosslinked Micelles Based Polyamidoamine for Effective Paclitaxel Delivery. J Nanomed Nanotechnol 5: 212. doi: 10.4172/2157-7439.1000212

Page 10 of 10

30. Hofmann UB, Westphal JR, Waas ET, Zendman AJ, Cornelissen IM, et al. (1999) Matrix metalloproteinases in human melanoma cell lines and xenografts: increased expression of activated matrix metalloproteinase-2 (MMP-2) correlates with melanoma progression. $\mathrm{Br} \mathrm{J}$ Cancer 81: 774-782.

31. Kim JH, Kim TH, Jang JW, Jang YJ, Lee KH, et al. (2001) Analysis of matrix metalloproteinase mRNAs expressed in hepatocellular carcinoma cell lines. Mol Cells 12: 32-40.

32. Murawaki Y, Ikuta Y, Okamoto K, Mimura K, Koda M, et al. (2000) Plasma matrix metalloproteinase-9 (gelatinase B) in patients with hepatocellular carcinoma. Res Commun Mol Pathol Pharmacol 108: 351-357

33. Sato H1, Takino T, Okada Y, Cao J, Shinagawa A, et al. (1994) A matrix metalloproteinase expressed on the surface of invasive tumour cells. Nature 370: 61-65.

34. Takahara T, Furui K, Yata Y, Jin B, Zhang LP, et al. (1997) Dual expression of matrix metalloproteinase-2 and membrane-type 1-matrix metalloproteinase in fibrotic human livers. Hepatology 26: 1521-1529.

35. Théret N, Musso O, Turlin B, Lotrian D, Bioulac-Sage $P$, et al. (2001) Increased extracellular matrix remodeling is associated with tumor progression in human hepatocellular carcinomas. Hepatology 34: 82-88.

36. Chau Y, Langer RS (2003) Important factors in designing targeted delivery of cancer therapeutics via MMP-2 mediation. J Control Release 91: 239-240.

37. Chau Y, Padera RF, Dang NM, Langer R (2006) Antitumor efficacy of a nove polymer-peptide-drug conjugate in human tumor xenograft models. Int $\mathrm{J}$ Cancer 118: 1519-1526.

38. Chau Y, Tan FE, Langer R (2004) Synthesis and characterization of dextranpeptide-methotrexate conjugates for tumor targeting via mediation by matrix metalloproteinase II and matrix metalloproteinase IX. Bioconjug Chem 15: 931 941

39. Tauro JR, Gemeinhart RA (2005) Matrix metalloprotease triggered delivery of cancer chemotherapeutics from hydrogel matrixes. Bioconjug Chem 16: 11331139 .

40. Vartak DG, Gemeinhart RA (2007) Matrix metalloproteases: underutilized targets for drug delivery. J Drug Target 15: 1-20.

41. Goldspiel BR (1997) Clinical overview of the taxanes. Pharmacotherapy 17 110S-125S.

42. Mazzo DJ, NguyenHuu JJ, Pagniez S, Denis P (1997) Compatibility of docetaxel and paclitaxel in intravenous solutions with polyvinyl chloride infusion materials. Am J Health Syst Pharm 54: 566-569.

43. Singer JW, Shaffer S, Baker B, Bernareggi A, Stromatt S, et al. (2005) Paclitaxe poliglumex (XYOTAX; CT-2103): an intracellularly targeted taxane. Anticancer Drugs 16: 243-254

44. Singla AK, Garg A, Aggarwal D (2002) Paclitaxel and its formulations. Int $J$ Pharm 235: 179-192.

45. Sparreboom A, van Zuylen L, Brouwer E, Loos WJ, de Bruijn P, et al. (1999) Cremophor EL-mediated alteration of paclitaxel distribution in human blood: clinical pharmacokinetic implications. Cancer Res 59: 1454-1457.

46. Ballatore C, Aspland SE, Castillo R, Desharnais J, Eustaquio T, et al. (2005) A facile route to paclitaxel C-10 carbamates. Bioorg Med Chem Lett 15: 2477 2480.

47. Chandran SS, Williams SA, Denmeade SR (2009) Extended-release PEGluciferin allows for long-term imaging of firefly luciferase activity in vivo. Luminescence 24: 35-38.

48. Greenwald RB, Choe YH, McGuire J, Conover CD (2003) Effective drug delivery by PEGylated drug conjugates. Adv Drug Deliv Rev 55: 217-250.

49. Duncan R (2003) The dawning era of polymer therapeutics. Nat Rev Drug Discov 2: 347-360.
50. von Maltzahn G, Harris TJ, Park JH, Min DH, Schmidt AJ, et al. (2007) Nanoparticle self-assembly gated by logical proteolytic triggers. J Am Chem Soc 129: 6064-6065.

51. Fortier G, Laliberte M (1993) Surface modification of horseradish peroxidase with polyethylene glycols of various molecular masses: Preparation of reagents and characterization of horseradish peroxidase-polyethylene glycol adducts. Biotechnol Appl Biochem 17: 115-130.

52. de Groot FM, van Berkom LW, Scheeren HW (2000) Synthesis and biological evaluation of 2'-carbamate-linked and 2'-carbonate-linked prodrugs of paclitaxel: selective activation by the tumor-associated protease plasmin. J Med Chem 43: 3093-3102.

53. Greenwald RB, Pendri A, Bolikal D (1995) Highly Water Soluble Taxo Derivatives: 7-Polyethylene Glycol Carbamates and Carbonates. J Org Chem 60: 331-336

54. Blacklock J, You YZ, Zhou QH, Mao G, Oupický D (2009) Gene delivery in vitro and in vivo from bioreducible multilayered polyelectrolyte films of plasmid DNA. Biomaterials 30: 939-950.

55. Antonietti M, Forster S (2003) Vesicles and liposomes: A self-assembly principle beyond lipids. Adv Mater 15: 1323-1333.

56. Discher DE, Eisenberg A (2002) Polymer vesicles. Science 297: 967-973.

57. Lee JC, Bermudez H, Discher BM, Sheehan MA, Won YY, et al. (2001) Preparation, stability, and in vitro performance of vesicles made with diblock copolymers. Biotechnol Bioeng 73: 135-145

58. Torchilin VP (2005) Recent advances with liposomes as pharmaceutical carriers. Nat Rev Drug Discov 4: 145-160.

59. Shahin M, Lavasanifar A (2010) Novel self-associating poly(ethylene oxide)b-poly(epsilon-caprolactone) based drug conjugates and nano-containers for paclitaxel delivery. Int J Pharm 389: 213-222.

60. Takae S, Miyata K, Oba M, Ishii T, Nishiyama N, et al. (2008) PEG-detachable polyplex micelles based on disulfide-linked block catiomers as bioresponsive nonviral gene vectors. J Am Chem Soc 130: 6001-6009.

61. Bartsch JE, Staren ED, Appert HE (2003) Matrix metalloproteinase expression in breast cancer. J Surg Res 110: 383-392.

62. Chebbi I, Migianu-Griffoni E, Sainte-Catherine O, Lecouvey M, Seksek O (2010) In vitro assessment of liposomal neridronate on MDA-MB-231 human breast cancer cells. Int J Pharm 383: 116-122.

63. Lee HS, Seo EY, Kang NE, Kim WK (2008) [6]-Gingerol inhibits metastasis of MDA-MB-231 human breast cancer cells. J Nutr Biochem 19: 313-319.

64. Paquette B, Bisson M, Baptiste C, Therriault H, Lemay R, et al. (2005) Invasiveness of breast cancer cells MDA-MB-231 through extracellular matrix is increased by the estradiol metabolite 4-hydroxyestradiol. Int J Cancer 113 706-711.

65. Liu K, Cang S, Ma Y, Chiao JW (2013) Synergistic effect of paclitaxel and epigenetic agent phenethyl isothiocyanate on growth inhibition, cell cycle arrest and apoptosis in breast cancer cells. Cancer Cell Int 13: 10 